\title{
Localized scleroderma - current treatment options
}

\author{
Twardzina ograniczona - aktualne metody terapeutyczne
}

Katarzyna Wolska-Gawron, Małgorzata Michalska-Jakubus, Dorota Krasowska

Department of Dermatology, Venereology and Paediatric Dermatology, Medical University of Lublin, Polska

Klinika Dermatologii, Wenerologii i Dermatologii Dziecięcej Uniwersytetu Medycznego w Lublinie, Poland

Dermatol Rev/Przegl Dermatol 2017, 104, 606-618 DOI: https://doi.org/I0.51 |4/dr.2017.71833

\author{
CORRESPONDING AUTHOR/ \\ ADRES DO KORESPONDENCJI: \\ lek. Katarzyna Wolska-Gawron \\ Klinika Dermatologii, Wenerologii \\ i Dermatologii Dziecięcej \\ Uniwersytet Medyczny w Lublinie \\ ul. Radziwiłłowska 13 \\ 20-080 Lublin, Polska \\ faks: +48 601334711 \\ e-mail: wolskak@poczta.onet.pl
}

\begin{abstract}
Localized scleroderma (morphea) is a connective tissue disease that affects the skin, subcutaneous tissue and underlying tissues including the fasciae, muscles and bones. The treatment of localized scleroderma depends on the clinical form of the disease, its severity/activity, extent of skin lesions and patient's age. Patients with limited skin involvement caused by morphea require topical therapy with glucocorticoids, calcineurin inhibitors, calcipotriol or UVA/PUVA phototherapy. More severe variants of localized scleroderma with extensive tissue involvement require immediate systemic therapy with glucocorticoids and/or methotrexate, or mycophenolate mofetil. According to recent reports, attempts have also been taken, with variable clinical outcomes, to treat localized scleroderma topically with pirfenidone and imiquimod, systemically with tacrolimus and cyclosporine; and with fractional $\mathrm{CO}_{2}$ laser, photodynamic therapy and autologous fat transfer. The article presents current therapeutic methods of localized scleroderma.
\end{abstract}

\section{STRESZCZENIE}

Twardzina ograniczona (morphea, localized scleroderma) jest chorobą tkanki łącznej, która manifestuje się zajęciem skóry, tkanki podskórnej oraz tkanek leżących poniżej - powięzi, mięśni lub kości. Leczenie twardziny ograniczonej zależy od postaci klinicznej, nasilenia lub aktywności choroby, rozległości wykwitów oraz wieku pacjenta. Pacjenci z ograniczonym zajęciem skóry w przebiegu morphea wymagają terapii miejscowej z zastosowaniem glikokortykosteroidów, inhibitorów kalcyneuryny, kalcypotriolu lub fototerapii (UVA/PUVA). W cięższych odmianach, w których dochodzi do rozległego zajęcia tkanek, należy jak najszybciej rozpocząć terapię ogólną z zastosowaniem glikokortykosteroidów i/lub metotreksatu, ewentualnie mykofenolanu mofetylu. Według najnowszych doniesień podejmowane są próby terapii twardziny ograniczonej z zastosowaniem pirfenidonu i imikwimodu miejscowo, takrolimusu i cyklosporyny ogólnie, lasera frakcyjnego $\mathrm{CO}_{2}$, terapii fotodynamicznej i autologicznego przeszczepu tkanki tłuszczowej z różnym efektem klinicznym. W pracy przedstawiono aktualne metody terapii twardziny ograniczonej.

Key words: glucocorticosteroids, methotrexate, phototherapy, therapy, tacrolimus, calcipotriol.

Słowa kluczowe: glikokortykosteroidy, metotreksat, fototerapia, terapia, takrolimus, kalcypotriol. 
Localized scleroderma (morphea) is a chronic connective tissue disease which is characterized by circumscribed cutaneous sclerosis, often with involvement of underlying tissues including the fasciae, muscles and bones $[1,2]$. The incidence of localized scleroderma is estimated at $0.4-2.7$ cases $/ 100,000$ population/year, with a peak age of onset at 20-40 years [3]. Women are more commonly affected than men $[2,3]$. The aetiopathogenesis of localized scleroderma has not been fully elucidated. The disease is believed to result from an overproduction and accumulation of collagen and extracellular matrix proteins in the skin and subcutaneous tissue, and less commonly in the fasciae, muscles and bones. A decisive role in the development of the disorder is attributed to genetic and environmental factors as well as vascular and immune disorders [2,3]. The evolution of skin lesions in localized scleroderma comprises three clinical stages: early inflammation, progressive sclerosis and atrophy $[2,3]$. In the majority of cases, the disease runs a mild course. However, there are also subtypes characterized by a severe course and associated with serious complications such as joint contractures, limb length reduction and deformities. The treatment of localized scleroderma depends on the clinical form of the disease, its severity/activity, extent of skin lesions and patient's age $[2,3]$.

\section{TOPICAL TREATMENT}

Topical treatment is used for mild forms of localized scleroderma which involve the dermis. In such cases, skin lesions do not usually produce subjective symptoms, however they are considered a cosmetic defect [1]. Available topical therapies include glucocorticoids, calcineurin inhibitors, vitamin $\mathrm{D}_{3}$ derivatives and new medications such as imiquimod or pirfenidone.

\section{Glucocorticoids}

Glucocorticoids are widely recognized for the treatment of the active phase of limited forms of localized scleroderma (plaque and guttate types, atrophoderma of Pasini and Pierini). Treatment is based on medications with moderate and high potency which should be used once daily for 1 month (high-potency glucocorticoids) or once daily for 3 months (medium-potency glucocorticoids) [2,3]. If topical treatment needs to be continued, intermittent therapy should be introduced [2]. To enhance the efficacy of steroid treatment, the medications listed above may be used under occlusion [2]. Intralesional injections of triamcinolone at a dose of 10-40 $\mathrm{mg}$ per $1 \mathrm{ml}$ (pure or diluted with lidocaine at a ratio of $1: 2$ or $1: 4$ ) may be used

\section{WPROWADZENIE}

Twardzina ograniczona jest przewlekłą chorobą tkanki łącznej, która charakteryzuje się ograniczonym stwardnieniem skóry, a także często zajęciem tkanek głębiej położonych - powięzi, mięśni, kości [1, 2]. Szacuje się, że zapadalność na twardzinę ograniczoną wynosi 0,4-2,7 przypadku/100 000/rok, a szczyt zachorowań przypada między 20. a 40. rokiem życia [3]. Choroba występuje częściej u płci żeńskiej $[2,3]$. Etiopatogeneza twardziny ograniczonej nie została w pełni poznana. Jej istotą jest nadprodukcja oraz odkładanie się kolagenu i białek macierzy pozakomórkowej w skórze, tkance podskórnej, rzadziej w powięziach, mięśniach i kościach. Przypuszcza się, że decydujące znaczenie mają czynniki genetyczne i środowiskowe, a także zaburzenia naczyniowe oraz immunologiczne [2, 3]. Ewolucja zmian skórnych obejmuje trzy fazy kliniczne: wczesną zapalną, postępującego stwardnienia i zanikową (atroficzną) $[2,3]$. W większości przypadków przebieg choroby jest łagodny. Istnieją jednak podtypy o ciężkim przebiegu z poważnymi powikłaniami, takimi jak przykurcze stawowe, skrócenie długości i deformacje kończyn. Leczenie twardziny ograniczonej jest uzależnione od postaci klinicznej, nasilenia lub aktywności choroby, rozległości wykwitów oraz wieku pacjenta $[2,3]$.

\section{LECZENIE MIEJSCOWE}

Terapia miejscowa znajduje zastosowanie w leczeniu łagodnych postaci twardziny ograniczonej, które przebiegają z zajęciem skóry właściwej. W takich przypadkach zmiany chorobowe nie wywołują przeważnie dolegliwości subiektywnych, ale stanowią defekt kosmetyczny [1]. W terapii zewnętrznej stosuje się glikokortykosteroidy, inhibitory kalcyneuryny, pochodne witaminy $\mathrm{D}_{3}$ oraz nowe leki, takie jak imikwimod czy pirfenidon.

\section{Glikokortykosteroidy}

Glikokortykosteroidy są uznaną metodą terapii aktywnej fazy twardziny ograniczonej (twardzina plackowata, twardzina grudkowa, twardzina ograniczona pierwotnie zanikowa). W leczeniu stosuje się preparaty o średniej i dużej sile działania, które należy aplikować raz dziennie przez miesiąc (glikokortykosteroidy o dużej sile działania) lub raz dziennie przez 3 miesiące (glikokortykosteroidy o umiarkowanej sile działania) [2, 3]. Gdy konieczne jest kontynuowanie leczenia miejscowego, należy wdrożyć terapię przerywaną [2]. Aby zwiększyć skuteczność steroidów, można stosować je pod okluzją [2]. Doogniskowe iniekcje triamcynolonu w dawce $10-40 \mathrm{mg} / \mathrm{ml}$ (ewentualnie rozcieńczone lidokainą w stosunku $1: 2$ lub $1: 4)$ stosuje się w przypadku 
to treat active lesions secondary to linear scleroderma "en coup de sabre" type as an adjuvant therapy [2,3].

\section{Calcineurin inhibitors}

Tacrolimus $0.1 \%$ is recognized as a therapeutic option alternative to glucocorticoids in the treatment of active lesions of localized scleroderma [2, 3]. The medication should be applied twice daily for 12 months [4]. Studies have shown tacrolimus to be effective both in the treatment of active erythematous lesions and sclerotic atrophic plaques [5]. In the studied group of patients treated with topical tacrolimus the therapy was found to eliminate active erythematous eruptions and reduce tissue density within disease lesions [5]. Stefanaki et al. stressed that tacrolimus therapy had good efficacy and there were no relapses of localized scleroderma lesions during a follow-up of 1 year after the completion of treatment [6]. So far, however, there have been no randomized clinical studies investigating tacrolimus and pimecrolimus [2].

\section{Vitamin $D_{3}$ derivatives}

Calcipotriol $0.005 \%$ is the recommended therapeutic option for active pre-sclerotic or mildly thickened lesions secondary to plaque-type scleroderma $[2,3$, 7]. The medication can be used in monotherapy (option unavailable in Poland) or in combination with betamethasone dipropionate. The highest efficacy of calcipotriol is achieved when the drug is used twice daily for a minimum of 3 months, preferably under occlusion $[2,7]$.

\section{Imiquimod}

Imiquimod is an immunomodulatory agent which reduces tissue fibrosis through the inhibition of transforming growth factor $\beta$ (TGF- $\beta$ ). There have been reports of effective treatment with imiquimod with respect to reduced dyspigmentation and induration of morphea lesions, however randomized clinical studies are as yet lacking [2,7]. Based on the current state of knowledge, the drug is not indicated for the treatment of localized scleroderma [2].

\section{Pirfenidone}

Pirfenidone is an immunosuppressive drug belonging to the class of pyridines which is used orally in the treatment of mild and moderate idiopathic pulmonary fibrosis. The medication exhibits antiinflammatory and antifibrotic effects which result from the suppression of the gene encoding TGF- $\beta$ [8]. Recent studies conducted in a group of 12 patients with localized scleroderma (6 - generalized localized scleroderma, 3 - linear scleroderma, 3 - plaque scleroderma) have demonstrated a good therapeutic effect aktywnych zmian w przebiegu twardziny ograniczonej typu cięcia szablą jako leczenie uzupełniające $[2,3]$.

\section{Inhibitory kalcyneuryny}

Takrolimus 0,1\% uznaje się za alternatywną do glikokortykosteroidów metodę terapii aktywnych ognisk twardziny ograniczonej $[2,3]$. Preparat stosuje się 2 razy dziennie przez 12 miesięcy [4]. W badaniu wykazano korzystne działanie preparatu zarówno na aktywne ogniska rumieniowe, jak i blaszki stwardnieniowo-zanikowe [5]. U chorych stosujących takrolimus miejscowo obserwowano ustąpienie aktywnych, zapalnych wykwitów oraz zmniejszenie spoistości tkanki w obrębie ognisk chorobowych [5]. Stefanaki i wsp. podkreślali dobrą skuteczność i brak nawrotów ognisk twardziny ograniczonej po roku od zakończenia terapii takrolimusem [6]. Dotychczas nie przeprowadzono badań klinicznych $\mathrm{z}$ randomizacją $\mathrm{w}$ zakresie stosowania takrolimusu i pimekrolimusu [2].

\section{Pochodne witaminy $D_{3}$}

Kalcypotriol 0,005\% jest zalecaną formą terapii aktywnych ognisk twardziny plackowatej w fazie przedstwardnieniowej lub nieznacznie wzmożonej spoistości [2, 3, 7]. Może być stosowany w monoterapii (niedostępny w Polsce) lub w połączeniu z dipropionianem betametazonu. Największą skuteczność uzyskuje się, stosując kalcypotriol 2 razy dziennie przez co najmniej 3 miesiące, zwłaszcza pod okluzją $[2,7]$.

\section{Imikwimod}

Imikwimod jest lekiem immunomodulującym, który zmniejsza włóknienie tkanek poprzez zahamowanie transformującego czynnika wzrostu $\beta$ (TGF- $\beta$ ). Opisano przypadki jego skuteczności w zmniejszaniu dyspigmentacji i stwardnienia wykwitów morphea, jednak nadal nie przeprowadzono $\mathrm{w}$ tym zakresie badań klinicznych z randomizacją [2, 7]. Według aktualnej wiedzy lek ten nie jest zalecany w terapii twardziny ograniczonej [2].

\section{Pirfenidon}

Pirfenidon jest lekiem immunosupresyjnym z grupy pirydyn, który stosuje się doustnie w terapii łagodnych i umiarkowanych postaci idiopatycznego włóknienia płuc. Preparat ma działanie przeciwzapalne i antyfibrotyczne, które wynika z supresji genu kodującego TGF- $\beta$ [8]. Najnowsze badania przeprowadzone u 12 chorych $\mathrm{z}$ twardziną ograniczoną (6 - twardzina ograniczona uogólniona, 3 - twardzina linijna, 3 - twardzina plackowata) wykazały dobry efekt terapeutyczny $8 \%$ pirfenidonu w kremie, który aplikowano 3 razy dziennie przez 6 miesięcy [8]. Sku- 
of $8 \%$ pirfenidone cream applied 3 times a day for 6 months [8]. The efficacy of treatment was evaluated with the modified Localized Scleroderma Skin Severity Index (mLoSSI), with a durometer and histopathological examination of skin biopsy [8]. The drug, however, requires further studies in a larger group of patients and with a longer duration of application [8].

\section{PHOTOTHERAPY}

Phototherapy is a recognized method for the treatment of localized scleroderma variants in which there is no involvement of the subcutaneous tissue, fasciae, muscles or bones $[2,7]$. UV radiation has antiinflammatory properties and contributes to the apoptosis of T cells and Langerhans cells, and lowers the concentration of interleukin 6 (IL-6) and TGF- $\beta$. In addition, it affects fibroblasts and increases the concentration of collagenases, leading to the inhibition of the process of fibrosis [2-4]. Phototherapy shows the greatest therapeutic effect in combination with topical therapy, e.g. glucocorticoids or vitamin $\mathrm{D}_{3}$ derivatives [2]. Before initiating the therapy, contraindications to phototherapy must be excluded, such as positive family history for UV-related skin cancers, use of photosensitizing and phototoxic substances, eye diseases (for PUVA therapy). Also, the patient's individual sensitivity to UV must be evaluated by determining the minimal phototoxic dose (MPD). The dose of phototherapy and the number of treatments should be decided for each patient on a case-by-case basis, taking into account their skin phototype, extent of skin lesions and disease activity [9].

\section{UVA-I}

UVA-1 phototherapy uses the wavelengths of 340-400 nm. It produces a therapeutic effect through its impact on factors that induce tissue fibrosis, i.e. immune dysregulation, collagen overproduction and endothelial cell dysfunction [9]. UVA-1 increases the concentration of collagenases (MMP, extracellular matrix metalloproteinases), decorin and interferon $\gamma(\mathrm{INF}-\gamma)$, and inhibits the production of TGF- $\beta$, hydroxyproline, IL-6 and IL-8 [10]. The frequency of UVA-1 is 3-5 times a week, and the total number of treatments is usually $\geq 30[2,3]$. UVA-1 phototherapy is normally used in three types of doses: low (10$\left.29 \mathrm{~J} / \mathrm{cm}^{2}\right)$, medium $\left(30-59 \mathrm{~J} / \mathrm{cm}^{2}\right)$ or high $(60-130 \mathrm{~J} /$ $\mathrm{cm}^{2}$ ) [2]. The wavelength range of UVA-1 radiation carries a lower risk of adverse reactions, the most common of which have included passing headaches and dry skin [9]. The risk of disease recurrence after the completion of UVA-1 phototherapy is not correlated with the age of patients, clinical form of localized scleroderma, skin phototype or radiation dose $[11,12]$. Recent teczność terapii oceniano przy zastosowaniu wskaźnika oceny aktywności lub nasilenia choroby (modified Localized Scleroderma Skin Severity Index - mLoSSI), durometru oraz badania histopatologicznego wycinka skóry [8]. Konieczne są jednak dalsze badania w większej grupie chorych i z dłuższym okresem stosowania leku [8].

\section{FOTOTERAPIA}

Fototerapia jest uznaną metodą leczenia odmian twardziny ograniczonej, w których nie dochodzi do zajęcia tkanki podskórnej, powięzi, mięśni czy kości [2, 7]. Promieniowanie UV ma właściwości przeciwzapalne, wpływa na apoptozę limfocytów $\mathrm{T}$ i komórek Langerhansa oraz zmniejsza stężenie interleukiny 6 (IL-6) i TGF- $\beta$. Dodatkowo działa na fibroblasty i zwiększa stężenie kolagenaz, co prowadzi do zahamowania procesu włóknienia [2-4]. Fototerapia przynosi najlepsze efekty w połączeniu $\mathrm{z}$ terapią miejscową, np. glikokortykosteroidami lub pochodnymi witaminy $\mathrm{D}_{3}$ [2]. Przed rozpoczęciem fototerapii należy wykluczyć przeciwwskazania, takie jak dodatni wywiad rodzinny w kierunku nowotworów skóry zależnych od UV, stosowanie substancji fotouczulających i fototoksycznych, choroby narządu wzroku (w przypadku PUVA-terapii). Powinno się także ustalić indywidualną wrażliwość pacjenta na UV poprzez określenie minimalnej dawki fototoksycznej (minimal phototoxic dose - MPD). Dawkę i liczbę naświetlań należy dostosowywać indywidualnie z uwzględnieniem fototypu skóry, rozległości zmian chorobowych oraz aktywności choroby [9].

\section{UVAI}

Fototerapia UVA1 wykorzystuje fale o długości 340-400 nm. Działanie terapeutyczne odbywa się poprzez wpływ na czynniki, które indukują włóknienie tkanek, takie jak dysregulacja immunologiczna, nadprodukcja kolagenu i dysfunkcja komórek śródbłonka [9]. UVA1 zwiększa stężenie kolagenaz (MMP, metaloproteinaz macierzy pozakomórkowej), dekoryny i interferonu $\gamma$ (INF- $\gamma$ ), a także hamuje produkcję TGF- $\beta$, hydroksyproliny, IL-6 i IL-8 [10]. Naświetlania wykonywane są 3-5 razy w tygodniu, najczęściej w łącznej liczbie $\geq 30[2,3]$. Powszechnie stosuje się trzy rodzaje dawek UVA1: małe (10-29 J/ $\left.\mathrm{cm}^{2}\right)$, średnie (30-59 J/ $\left.\mathrm{cm}^{2}\right)$ lub duże $\left(60-130 \mathrm{~J} / \mathrm{cm}^{2}\right)$ [2]. Zakres promieniowania UVA1 wiąże się z mniejszym ryzykiem wystąpienia działań niepożądanych, z których najczęstsze są przemijające bóle głowy i suchość skóry [9]. Ryzyko nawrotu choroby po zakończeniu fototerapii UVA1 nie koreluje $\mathrm{z}$ wiekiem pacjenta, odmianą kliniczną twardziny ograniczonej, fototypem skóry i dawką promieniowania [11, 12]. Najnowsze doniesienia wskazują, że prawdopodo- 
reports have shown that the probability of recurrence of active lesions is about $44.5 \%$ and $48.4 \%$, respectively, 2 and 3 years after completed treatment [12].

\section{Broadband UVA}

UVA1 phototherapy (320-400 nm) is a commonly used treatment method for localized scleroderma, particularly in Poland. A study conducted in a group of 63 patients with localized scleroderma has demonstrated a similar therapeutic effect for all three dosages used $\left(5,10\right.$ and $\left.20 \mathrm{~J} / \mathrm{cm}^{2}\right)$ after a completed cycle of 20 irradiations [2,3]. So far, however, there have been no analyses comparing broadband UVA with other phototherapy modalities $[2,3]$.

\section{PUVA}

PUVA comprises UVA phototherapy in combination with psoralen which can be administered either topically (PUVA-bath, PUVA-soak) or orally. PUVA's mechanism of action is based on decreasing the concentration of vascular cell adhesion molecules (VCAM) and increasing the serum level of tumour necrosis factor $\alpha$ (TNF- $\alpha$ ) in patients with localized scleroderma [10]. Systemic therapy should begin with a dose equivalent to $50-70 \%$ of MPD, and topical therapy with a dose corresponding to $30 \%$ of MPD $[3,7]$. The frequency of PUVA is 2-3 times a week, and the total number of PUVA treatments is usually equal to $30[2,3]$. PUVA shows the greatest efficacy in cases of early inflammatory lesions secondary to localized scleroderma $[3,13]$.

\section{Photodynamic therapy}

Photodynamic therapy (PDT) is a therapeutic modality based on the phototoxic reaction induced by an interaction between a photosensitizing substance and light at an appropriate wavelength (570-670 nm). The most widely used activator is $5 \% 5$-aminolevulinic acid (ALA). The method exerts antiinflammatory properties by increasing the synthesis of IL-10, and inhibits the process of fibrosis through its effect on TGF- $\beta$ [14]. A study conducted in a group of 6 patients with localized scleroderma treated with PDT has demonstrated a significant therapeutic effect in 4 subjects [10]. Photodynamic therapy treatments were applied at weekly intervals (6 treatments in total) with light at a wavelength of $570-670 \mathrm{~nm}$, at a dose of $25 \mathrm{~J} / \mathrm{cm}^{2}$ [10].

\section{SYSTEMIC TREATMENT}

\section{Glucocorticoids}

Systemic glucocorticoids (oral or intravenous) are a class of drugs which are commonly used in the ther- bieństwo nawrotu aktywnych ognisk chorobowych wynosi ok. $44,5 \%$ i $48,4 \%$ po upływie odpowiednio 2 i 3 lat od zakończenia kuracji [12].

\section{Fototerapia UVA szerokopasmowa}

Fototerapia UVA1 (320-400 nm) jest często stosowana w leczeniu twardziny ograniczonej, zwłaszcza w Polsce. W badaniu przeprowadzonym u 63 pacjentów z twardziną ograniczoną wykazano podobny efekt terapeutyczny każdej z trzech dawek: 5, 10, 20 $\mathrm{J} / \mathrm{cm}^{2}[2,3]$ po zakończeniu cyklu 20 naświetlań $[2,3]$. Dotychczas nie opublikowano analiz porównujących szerokopasmową fototerapię UVA z innymi metodami fototerapii $[2,3]$.

\section{PUVA}

Terapia PUVA polega na połączeniu UVA z psoralenem, który może być aplikowany miejscowo (PUVA-bath, PUVA-soak) lub doustnie. Mechanizm działania PUVA-terapii polega na redukcji stężenia cząsteczek adhezji komórkowej naczyń (VCAM) oraz zwiększaniu poziomu czynnika martwicy nowotworu $\alpha$ (TNF- $\alpha$ ) w surowicy pacjentów z twardziną ograniczoną [10]. Terapię ogólną rozpoczyna się od dawki odpowiadającej 50-70\% MPD, a terapię miejscową od dawki stanowiącej 30\% MPD [3, 7]. Naświetlania wykonuje się 2-3 razy w tygodniu, najczęściej w łącznej liczbie 30 [2, 3]. Terapia PUVA charakteryzuje się największą skutecznością w przypadku wczesnych, zapalnych ognisk twardziny ograniczonej $[3,13]$.

\section{Terapia fotodynamiczna}

Terapia fotodynamiczna (photodynamic therapy PDT) jest metodą, która wykorzystuje reakcję fototoksyczną indukowaną oddziaływaniem substancji fotouczulającej i światła o długości fali 570-670 nm. Najczęściej stosowanym aktywatorem jest 5\% kwas 5-aminolewulinowy (ALA). Terapia fotodynamiczna działa przeciwzapalnie poprzez zwiększanie syntezy IL-10, a także hamuje proces włóknienia poprzez wpływ na TGF- $\beta$ [14]. W badaniu przeprowadzonym u 6 pacjentów z twardziną ograniczoną poddanych PDT wykazano znaczący efekt terapeutyczny u 4 chorych [10]. Naświetlania wykonano w odstępach tygodniowych (łącznie 6 naświetlań) z zastosowaniem światła o długości fali 570-670 nm w dawce $25 \mathrm{~J} / \mathrm{cm}^{2}$ [10].

\section{LECZENIE OGÓLNE}

\section{Glikokortykosteroidy}

Glikokortykosteroidy podawane ogólnie (doustnie lub dożylnie) są powszechnie stosowane $\mathrm{w}$ terapii 
apy of severe forms of localized scleroderma - linear, deep, generalized and mixed types, and eosinophilic fasciitis $[2,3,7]$. The best therapeutic outcomes are achieved in the treatment of early active disease lesions [3, 7]. The efficacy of systemic glucocorticoids has been demonstrated in a number of retrospective and cohort studies, however randomized double-blind placebo-controlled clinical trials are still lacking [15]. According to the European Dermatology Forum guidelines issued in 2016, severe forms of localized scleroderma with extensive tissue lesions or involvement of underlying tissues (subcutaneous tissue, fasciae, muscles and bones) should be treated with intravenous pulses of methylprednisolone at doses in the range of 500-1,000 mg/day for 3 days over a period of 3-6 consecutive months [2,3]. An alternative to intravenous treatment is oral therapy which, however, is associated with a higher risk of adverse reactions $[2,3,15]$. Prednisolone is recommended for oral use, at a dose of $0.5-2 \mathrm{mg} / \mathrm{kg} /$ day for 2-4 weeks, followed by gradual dose reduction $[2,3]$. Glucocorticoids can be used in monotherapy or in combination with methotrexate in cases that are refractory to steroid therapy $[2,3,7]$.

\section{Methotrexate}

Methotrexate (MTX) is the most extensively studied of all the systemic therapeutic agents used for moderate and severe forms of localized scleroderma - generalized, deep and linear types [16]. Overall, one randomized double-blind placebo-controlled study, and three prospective and four retrospective studies have been published, demonstrating that MTX is an effective agent in the treatment of localized scleroderma. According to guidelines issued by the European Dermatology Forum in 2016 and the Childhood Arthritis and Rheumatology Research Alliance (CARRA) in 2012, the therapy of severe forms of localized scleroderma with extensive tissue lesions or involvement of underlying tissues (subcutaneous tissue, fasciae, muscles and bones) should be based on MTX (at doses ranging from 12.5 to $25 \mathrm{mg}$ / week in adults and at a dose of $15 \mathrm{mg} / \mathrm{m}^{2} /$ week, maximum $25 \mathrm{mg} /$ week, in children), either in monotherapy or in combination with systemic glucocorticoids (at doses given above) $[2,3,16]$. According to Kreuter et al., combined therapy with MTX and glucocorticoids is the most efficacious in generalized localized scleroderma and in the active phase of linear localized scleroderma in paediatric patients [7]. The duration of therapy, both in adults and children, should depend on the clinical response and should not be shorter than 12 months [3].

\section{Mycophenolate mofetil}

Mycophenolate mofetil (MMF) is a drug exhibiting cytostatic activity against $\mathrm{T}$ and $\mathrm{B}$ cells. Mycophe- ciężkich postaci twardziny ograniczonej - linijnej, głębokiej, uogólnionej, mieszanej, oraz eozynofilowego zapalenia powięzi $[2,3,7]$. Najlepsze efekty uzyskuje się w leczeniu wczesnych, aktywnych ognisk chorobowych [3, 7]. Skuteczność glikokortykosteroidów stosowanych ogólnie potwierdzono w licznych badaniach retrospektywnych i kohortowych, jednak nie ma badań klinicznych $\mathrm{z}$ randomizacją przeprowadzonych metodą podwójnie ślepej próby z placebo [15]. Według European Dermatology Forum z 2016 r. w terapii ciężkich postaci twardziny ograniczonej z rozległym zajęciem tkanek lub z zajęciem tkanek głębiej położonych (tkanki podskórnej, powięzi, mięśni, kości) należy zastosować dożylnie pulsy metyloprednizolonu w dawce 500-1000 mg/dobę przez 3 dni przez kolejne 3-6 miesięcy [2,3]. Alternatywą dla kuracji dożylnej jest terapia doustna, która wiąże się jednak z większym ryzykiem wystąpienia działań niepożądanych $[2,3,15]$. Zaleca się stosowanie prednizolonu doustnie w dawce 0,5-2 mg/kg m.c./dobę przez 2-4 tygodnie, a następnie stopniową redukcję dawki [2, 3]. Glikokortykosteroidy mogą być stosowane w monoterapii lub w połączeniu z metotreksatem w przypadkach nieodpowiadających na steroidoterapię $[2,3,7]$.

\section{Metotreksat}

Metotreksat (MTX) jest najlepiej przebadanym lekiem stosowanym w terapii ogólnej średnio ciężkich i ciężkich odmian klinicznych twardziny ograniczonej - uogólnionej, głębokiej i linijnej [16]. Opublikowano jedno badanie kliniczne $\mathrm{z}$ randomizacją przeprowadzone metodą podwójnie ślepej próby z placebo, trzy badania prospektywne i cztery badania retrospektywne, które dowiodły skuteczności metotreksatu w leczeniu twardziny ograniczonej. Zgodnie z zaleceniami European Dermatology Forum z 2016 r. i Childchood Arthritis and Rheumatology Research Alliance (CARRA) z 2012 r. $\mathrm{w}$ terapii ciężkich postaci twardziny ograniczonej przebiegających z rozległym zajęciem tkanek lub zajęciem tkanek głębiej położonych (tkanki podskórnej, powięzi, mięśni, kości) należy zastosować MTX (dorośli - dawka 12,5-25 mg tygodniowo, dzieci - dawka $15 \mathrm{mg} / \mathrm{m}^{2}$ tygodniowo, maks. $25 \mathrm{mg}$ tygodniowo) w monoterapii lub w połączeniu z glikokortykosteroidami stosowanymi ogólnie (dawkowanie jak powyżej) [2, 3, 16]. Według Kreutera i wsp. terapia skojarzona MTX z glikokortykosteroidami jest najskuteczniejsza w przypadku twardziny ograniczonej uogólnionej oraz aktywnej fazy twardziny ograniczonej linijnej u pacjentów pediatrycznych [7]. Czas trwania terapii, zarówno u dorosłych, jak i u dzieci, powinien zależeć od odpowiedzi klinicznej i wynosić przynajmniej 12 miesięcy [3].

\section{Mykofenolan mofetylu}

Mykofenolan mofetylu (MMF) działa cytostatycznie na limfocyty T i B. Może być stosowany jako lek 
nolate mofetil can be used for second-line treatment in cases of inefficacy/intolerance of glucocorticoids or MTX, either in monotherapy or in combination with MTX [3, 17, 18]. The year 2009 saw the publication of results of the first study conducted in a group of 10 children with severe localized scleroderma (5 cases - linear type, 3 cases - generalized type and 2 cases - deep type) refractory to glucocorticoids and MTX, treated with MMF orally at doses in the range of $600-1,200 \mathrm{mg} / \mathrm{m}^{2}$ twice a day [18]. Clinical improvement was noted in the majority of patients (reduced number of inflammatory lesions 7/10, decreased density of lesions $9 / 10$, improvement in joint contractures 3/10) after 3.5 months of therapy [18] Mycophenolate mofetil treatment was not found to cause any adverse reactions. Dyspepsia occurred in one out of 10 children during the $27^{\text {th }}$ month after the completion of therapy [18].

\section{Antibiotics}

Penicillin has been used for the treatment of localized scleroderma for many years because of a postulated causal relationship between Borrelia burgdorferi infection and the development of lesions with morphological features of localized scleroderma [2, 3, 7]. The drug is administered in the form of intravenous infusions for 14-21 days. An alternative to penicillin is ceftriaxone $[3,7]$. Penicillin has antiinflammatory activity, and contributes to eliminating early erythematous skin lesions in localized scleroderma, however it has not been found to exhibit antifibrotic properties [2, 3, 7].

\section{Vascular drugs}

Pentoxifylline and sulodexide are agents which improve vascular flow and prevent endothelial cell dysfunction. Pentoxifylline stimulates the synthesis and release of prostacyclin, and reduces platelet adhesion and aggregation [19]. In addition, it enhances the flexibility of erythrocyte cell membrane, reduces blood viscosity and decreases plasminogen and antiplasmin activity [19]. Pentoxifylline also produces an antiinflammatory effect (by reducing the serum concentration of cytokines including IL-1, IL-6 and TNF- $\alpha$ ) as well as fibrinolytic and antioxidative effects [19]. Pentoxifylline is used orally at a dose of $400 \mathrm{mg} /$ day or parenterally at a dose of 150-300 mg/ day. Sulodexide has an antithrombotic effect resulting from the inhibition of factor Xa and blood platelet aggregation, and activation of the fibrinolytic system $[20,21]$. The drug improves the rheological properties of blood by lowering the plasma concentration of fibrinogen, and promotes connective tissue regeneration. In addition, sulodexide inhibits the expression of genes responsible for the synthesis of a range of drugiego wyboru w przypadku nieskuteczności lub nietolerancji glikokortykosteroidów lub MTX, w monoterapii lub w ich skojarzeniu [3, 17, 18]. W 2009 r. opublikowano wyniki pierwszego badania przeprowadzonego u 10 dzieci z ciężką twardziną ograniczoną (5 przypadków - twardzina linijna, 3 - twardzina uogólniona, 2 - twardzina głęboka), oporną na leczenie glikokortykosteroiami i MTX, u których zastosowano MMF doustnie w dawce $600-1200 \mathrm{mg} / \mathrm{m}^{2}$ 2 razy dziennie [18]. U większości pacjentów stwierdzono poprawę kliniczną (redukcję liczby zmian zapalnych $7 / 10$ pacjentów, zmniejszenie spoistości ognisk 9/10 oraz przykurczów stawowych 3/10) po 3,5 miesiąca terapii [18]. W czasie leczenia MMF nie wykazano żadnych działań niepożądanych. U 1 z 10 dzieci wystąpiła dyspepsja w 27. miesiącu po zakończeniu terapii [18].

\section{Antybiotyki}

Penicylina jest lekiem stosowanym od wielu lat w leczeniu twardziny ograniczonej ze względu na sugerowany związek przyczynowy między infekcją Borrelia burgdorferi a rozwojem zmian o morfologii twardziny ograniczonej [2, 3, 7]. Lek stosuje się w postaci wlewów dożylnych podawanych przez 1421 dni. Alternatywę dla penicyliny stanowi ceftriakson $[3,7]$. Penicylina ma działanie przeciwzapalne, wpływa korzystnie na wczesne rumieniowe ogniska twardziny ograniczonej, jednak nie potwierdzono jej właściwości antyfibrotycznych [2, 3, 7].

\section{Leki naczyniowe}

Pentoksyfilina i sulodeksyd to leki, które usprawniają przepływ naczyniowy i zapobiegają dysfunkcji komórek śródbłonka. Pentoksyfilina pobudza syntezę i uwalnianie prostacykliny oraz zmniejsza adhezję i agregację płytek [19]. Dodatkowo zwiększa elastyczność błony komórkowej erytrocytów, zmniejsza lepkość krwi oraz aktywność plazminogenu i antyplazminy [19]. Lek ma również działanie przeciwzapalne (obniża stężenia cytokin w surowicy, m.in. IL-1, IL-6, TNF- $\alpha$ ), fibrynolityczne i antyoksydacyjne [19]. Pentoksyfilina jest stosowana doustnie w dawce $400 \mathrm{mg} /$ dobę lub parenteralnie $\mathrm{w}$ dawce 150-300 mg/dobę. Sulodeksyd ma działanie przeciwzakrzepowe związane z hamowaniem czynnika Xa i agregacji płytek krwi oraz aktywacją układu fibrynolitycznego [20, 21]. Lek poprawia reologiczne właściwości krwi przez zmniejszenie stężenia fibrynogenu w osoczu, a także ułatwia regenerację tkanki łącznej. Ponadto hamuje ekspresję genów odpowiedzialnych za syntezę m.in. IL-6, TGF- $\beta$, VCAM, czynnika von Willebranda (VWF) [20, 21]. Preparat stosuje się doustnie w dawce 500 LSU/dobę w dwóch dawkach podzielonych i dożylnie w dawce 600-1200 LSU/dobę. 
factors including IL-6, TGF- $\beta$, VCAM and von Willebrand factor (VWF) $[20,21]$. The drug is used orally at a total dose of $500 \mathrm{LSU} /$ day in two divided doses and intravenously at a dose of 600-1,200 LSU/day.

\section{Calcineurin inhibitors}

Recent reports have pointed to the efficacy of oral cyclosporin and tacrolimus in the therapy of severe forms of localized scleroderma. Bali et al. [22] have conducted a study in a group of 12 patients with LoSc ( 9 - generalized form, 2 - linear form involving the extremities, 1 - progressive facial hemiatrophy), demonstrating a good therapeutic effect of cyclosporin A (with complete response to treatment noted in $5 / 12$ patients and partial response in $6 / 12$ patients). In the majority of subjects improvement was observed after 1-2 months of therapy with cyclosporin A at an average dose of $2.4 \mathrm{mg} / \mathrm{kg} /$ day. After a mean period of 18.6 months the extent of disease lesions expressed as body surface area (BSA) was found to decrease from $50 \%$ to $17 \%$. The authors suggest that cyclosporin A introduced at an early stage of the disease may prevent progressive tissue fibrosis and joint contractures [22].

\section{Retinoids}

The literature contains reports on the efficacy of systemic retinoids in the treatment of localized scleroderma. The first large study evaluating the efficacy of etretinate in the treatment of localized scleroderma was conducted in 1990 [23]. The study group comprised 50 patients who took etrinate at a dose of $1 \mathrm{mg} / \mathrm{kg} /$ day for 2 weeks or $0.6-0.8 \mathrm{mg} / \mathrm{kg} /$ day for 4-6 weeks [23]. The therapy produced a reduction in subjective symptoms (burning and itching sensation in the skin) in all studied patients, a complete remission of skin eruptions in 4 out of 50 patients and a significant clinical improvement in 40 subjects [23].

\section{ALTERNATIVE THERAPIES}

\section{Surgical treatment}

Surgery is indicated primarily for the treatment of joint contractures and limb asymmetry secondary to linear subtypes of localized scleroderma, and for reconstructive procedures in cosmetic defects resulting from atrophic lesions of the skin and underlying tissues [2, 3, 7]. Surgical interventions should only be considered in the inactive stage of the disease to minimize the risk of relapse [2,3]. If markers of active disease process are present, postoperative immunosuppressive therapy should be considered [2,3]. Limb length asymmetry secondary to linear localized scleroderma can be corrected by epiphysiodesis (delaying/stopping bone growth in the healthy extremity

\section{Inhibitory kalcyneuryny}

Najnowsze doniesienia wskazują na skuteczność cyklosporyny A i takrolimusu stosowanych doustnie w terapii ciężkich odmian twardziny ograniczonej. Bali i wsp. [22] przeprowadzili badanie u 12 pacjentów z twardziną ograniczoną ( 9 - postać uogólniona, 2 - twardzina linijna kończyn, 1 - postępujący zanik połowiczy twarzy), w którym wykazali dobry efekt terapeutyczny cyklosporyny A (całkowita odpowiedź na leczenie u 5 z 12 pacjentów, częściowa - u 6 z 12). U większości pacjentów stwierdzono poprawę po 1-2 miesiącach terapii cyklosporyną A w średniej dawce 2,4 mg/kg m.c./dobę. Po średnim czasie 18,6 miesiąca zmniejszyła się rozległość ognisk chorobowych (body surface area - BSA) z 50\% do 17\%. Autorzy sugerują, że cyklosporyna A podana we wczesnej fazie choroby może zapobiec postępującemu włóknieniu tkanek i przykurczom stawowym [22].

\section{Retinoidy}

W piśmiennictwie są doniesienia o skuteczności retinoidów stosowanych ogólnie w leczeniu twardziny ograniczonej. Pierwsze duże badanie z zastosowaniem etretynatu $\mathrm{w}$ leczeniu twardziny ograniczonej pochodzi z 1990 r. [23]. Grupa badana obejmowała 50 pacjentów, którzy przyjmowali etretynat w dawce $1 \mathrm{mg} / \mathrm{kg}$ m.c./dobę przez 2 tygodnie lub 0,6-0,8 mg/ $\mathrm{kg}$ m.c./dobę przez 4-6 tygodni [23]. Efektem terapii była redukcja objawów subiektywnych (uczucia pieczenia i świądu skóry) u wszystkich badanych, całkowita remisja wykwitów chorobowych u 4 z 50 pacjentów oraz znacząca poprawa kliniczna u 40 osób [23].

\section{ALTERNATYWNE FORMY TERAPII}

\section{Zabiegi chirurgiczne}

Operacje są zarezerwowane przede wszystkim do terapii przykurczów stawowych i asymetrii kończyn w przebiegu linijnych podtypów twardziny ograniczonej oraz stosowane jako zabiegi rekonstrukcyjne przy defektach kosmetycznych będących skutkiem zmian zanikowych skóry i tkanek położonych poniżej $[2,3,7]$. Procedury zabiegowe powinny być przeprowadzane $\mathrm{w}$ nieaktywnej fazie choroby, aby zminimalizować ryzyko nawrotu $[2,3]$. W przypadku obecności wykładników aktywnego procesu chorobowego należy rozważyć wdrożenie pooperacyjnej terapii immunosupresyjnej [2,3]. Asymetria długości kończyn w przebiegu twardziny ograniczonej linijnej może być korygowana zabiegiem epifizjodezy (spowolnienie lub zahamowanie wzrostu kości zdrowej kończyny poprzez zablokowanie chrząstek nasadowych) lub skrócenia ścięgna Achillesa [2, 3]. W przypadku twardziny ograniczonej linijnej przebiegającej 
by blocking epiphyseal cartilages) or surgical shortening of the Achilles tendon [2,3]. Plastic surgery may be considered in cases of linear localized scleroderma with face involvement (localized scleroderma en coup de sabre, progressive facial hemiatrophy) in order to improve facial contour $[2,3,7]$. The best therapeutic effects are achieved with autologous fat transplants [24]. Subcutaneous tissue is a widely accessible, biocompatible and inexpensive filler which can be used for repeated treatments [24]. The application of synthetic materials such as silicone, hyaluronic acid or lactic acid is associated with the risk of inflammatory reaction, dyspigmentation and scarring [24]. There have also been reports of localized scleroderma en coup de sabre and progressive facial hemiatrophy corrected by cranioplasty, placement of orbital implants and injections of botulinum toxin [17].

\section{Fractional $\mathrm{CO}_{2}$ laser}

Shalaby et al. have published the results of a study conducted in a group of 17 patients with localized scleroderma (plaque and linear types), in whom two comparable localized scleroderma lesions were treated by UVA-1 phototherapy (low doses: $30 \mathrm{~J} / \mathrm{cm}^{2}$, 30 exposures) or fractional $\mathrm{CO}_{2}$ laser procedures (10, $600 \mathrm{~nm}, 25 \mathrm{~W}, 3$ exposures) [25]. The lesions subjected to irradiation were selected on the basis of identical morphological features [25]. Clinical effects were evaluated clinically using the Localized Scleroderma Assessment Tool (LoSCAT) score: localized scleroderma lesions treated by $\mathrm{CO}_{2}$ laser showed very good response to therapy in 7 cases, good response in 9 cases, and fair response in 1 case; lesions treated by UVA-1 exhibited good response in 6 cases, fair response in 10 cases, and no response in 1 case; level of patient satisfaction - significantly higher for $\mathrm{CO}_{2}$ laser treatment; ultrasound assessment - significantly higher degree of reduction in skin thickness associated with $\mathrm{CO}_{2}$ laser treatment; histopathological evaluation - significantly higher improvement with respect to collagen homogenization for $\mathrm{CO}_{2}$ laser treatment and significantly reduced inflammatory infiltrate after UVA-1 treatments; and immunohistochemical assessment - no statistically significant differences between $\mathrm{CO}_{2}$ laser and UVA1 treatments with regard to the effect on the level of TGF- $\beta$ and MMP1 expression [25].

\section{Physiotherapy}

Physiotherapy is a very important component of multimodal therapy of localized scleroderma - linear, generalized, deep and mixed types [2, 3]. Physiotherapeutic procedures should not be used during the active inflammatory phase of the disease $[2,3,7]$. Inactive sclerotic lesions in localized scleroderma can be treated with massage and lymphatic drainage $[2,3,7]$. z zajęciem twarzy (twardzina typu cięcia szablą, postępujący zanik połowiczy twarzy) można rozważyć zabiegi chirurgii plastycznej, które poprawiają kontur twarzy $[2,3,7]$. Najlepsze efekty uzyskuje się dzięki autologicznym przeszczepom tkanki tłuszczowej [24]. Tkanka podskórna jest powszechnie dostępnym, biokompatybilnym i niedrogim wypełniaczem, którego aplikacja może być wielokrotnie powtarzana [24]. Zastosowanie materiałów syntetycznych, takich jak silikon, kwas hialuronowy i kwas mlekowy, wiąże się z ryzykiem wystąpienia odczynu zapalnego, dyspigmentacji oraz blizn [24]. Opisywano również przypadki twardziny ograniczonej typu cięcia szablą i postępującego zaniku połowiczego twarzy korygowanych zabiegami kranioplastyki, implantacją wczepów oczodołowych oraz iniekcjami toksyny botulinowej [17].

\section{Laser frakcyjny $\mathrm{CO}_{2}$}

Shalaby i wsp. przedstawili wyniki badania u 17 pacjentów z twardziną ograniczoną (plackowatą i linijną), u których dwa porównywalne ogniska chorobowe zostały poddane fototerapii UVA1 (małe dawki $30 \mathrm{~J} / \mathrm{cm}^{2}, 30$ ekspozycji) lub zabiegom z zastosowaniem lasera frakcyjnego $\mathrm{CO}_{2}(10,600 \mathrm{~nm}, 25 \mathrm{~W}, 3$ ekspozycje) [25]. Naświetlane ogniska dobierano w taki sposób, aby morfologia wykwitów była identyczna [25]. Efekty kliniczne porównywano na podstawie wyników w skali LoSCAT (Localized Scleroderma Assessment Tool): ogniska twardziny ograniczonej poddawane działaniu lasera $\mathrm{CO}_{2}$ wykazały bardzo dobrą odpowiedź na terapię w 7 przypadkach, dobrą - w 9, słabą - w 1; wykwity naświetlane UVA1 wykazały dobrą odpowiedź w 6 przypadkach, słabą - w 10, brak - w 1; satysfakcja pacjentów była istotnie większa w przypadku lasera $\mathrm{CO}_{2}$, ocena ultrasonograficzna wykazała istotnie większy stopień redukcji grubości skóry w przypadku lasera $\mathrm{CO}_{2}$, ocena histopatologiczna - istotnie większy stopień poprawy $\mathrm{w}$ zakresie homogenizacji kolagenu w przypadku lasera $\mathrm{CO}_{2} \mathrm{i}$ istotnie mniejszy naciek zapalny po naświetlaniach UVA1, ocena immunohistochemiczna brak istotnych statystycznie różnic między laserem $\mathrm{CO}_{2}$ i UVA1 w zakresie wpływu na poziom ekspresji TGF- $\beta$ i MMP1 [25].

\section{Fizjoterapia}

Fizjoterapia jest bardzo ważnym elementem multimodalnej terapii twardziny ograniczonej - postaci linijnej, uogólnionej, głębokiej oraz mieszanej [2, 3]. Zabiegi fizjoterapeutyczne nie powinny być przeprowadzane w aktywnej, zapalnej fazie choroby [2, $3,7]$. W przypadku nieaktywnych, stwardnieniowych ognisk twardziny ograniczonej można zastosować masaż i drenaż limfatyczny [2, 3, 7]. Zabiegi są za- 
Physiotherapy should be carried out once or twice a week for at least 3 months $[2,7]$.

\section{THERAPEUTIC MANAGEMENT IN ADULTS}

The choice of therapeutic modality for localized scleroderma based on the clinical form and disease activity/severity is shown in table $1[2,3,13]$.

\section{Plaque-type localized scleroderma}

The treatment of choice in plaque-type localized scleroderma with active inflammatory lesions is topical glucocorticoid therapy (high-potency glucocorticoids - once daily, maximum for a month, medium-potency glucocorticoids - once daily, maximum for 3 months; longer duration is possible in intermittent therapy) [2,3]. Alternative medications are calcineurin inhibitors (tacrolimus) or vitamin $\mathrm{D}_{3}$ derivatives (calcipotriol/calcipotriol + betamethasone) applied topically once or twice daily [2, 3, 13]. PUVA/UVA phototherapy can be used alone or in combination with topical medications. UVA treatments should be carried out at a frequency of 3-5 times a week, at a dose of $50-80 \mathrm{~J} / \mathrm{cm}^{2}$, with a total of 40 exposures. PUVA therapy requires 30 treatments applied between 2 and 4 times a week $[2,3,13]$.

Linear localized scleroderma (scleroderma en coup de sabre, progressive facial hemiatrophy, linear scleroderma of the limbs) and deep localized scleroderma

Cases of linear and deep localized scleroderma involving the subcutaneous tissue, fasciae, muscles, bones and joints require aggressive therapy in the active stage of the disease (appearance of new/expansion of pre-existing skin lesions, "lilac ring", erythematous (inflammatory) lesions, sclerotic plaques) $[2,3]$. The drugs of choice are glucocorticoids in the form of intravenous infusions of methylprednisolone at a dose of 500-1,000 mg/day for 3 days. Treatment should be continued for at least 3-6 months. An alternative to parenteral treatment is oral therapy with prednisolone. The drug should be used at a dose of $0.5-2 \mathrm{mg} / \mathrm{kg} /$ day for 2-4 weeks, followed by gradual dose reduction $[2,3]$. Glucocorticoids can be used in monotherapy or in combination with MTX. The recommended dose of MTX in adults is $12.5-25 \mathrm{mg} /$ week. Treatment should be continued for 12 months as a minimum $[2,3]$. Intolerance of or resistance to MTX are indications to consider MMF (1-2 g/day) $[2,3]$. The treatment of linear and deep forms of localized scleroderma should be initiated at an early disease stage in order to prevent complications such as dermatogenous contractures, joint contractures and limb asymmetry $[2,3]$. zwyczaj wykonywane 1-2 razy tygodniowo przez co najmniej 3 miesiące $[2,7]$.

\section{POSTĘPOWANIE TERAPEUTYCZNE U DOROSŁYCH}

Wybór metody leczenia twardziny ograniczonej w zależności od postaci klinicznej i aktywności lub nasilenia choroby przedstawiono $\mathrm{w}$ tabeli $1[2,3,13]$.

\section{Twardzina ograniczona plackowata}

Postępowaniem z wyboru w przypadku twardziny ograniczonej plackowatej, w której występują aktywne ogniska zapalne, jest terapia miejscowa glikokortykosteroidami (leki o dużej sile działania - raz dziennie, maksymalnie przez miesiąc; leki o umiarkowanej sile działania - raz dziennie, maksymalnie przez 3 miesiące; dłuższy czas leczenia możliwy w przypadku terapii przerywanej) [2, 3]. Preparatami alternatywnymi są inhibitory kalcyneuryny (takrolimus) lub pochodne witaminy $\mathrm{D}_{3}$ (kalcypotriol lub kalcypotriol + betametazon) aplikowane miejscowo 1-2 razy dziennie $[2,3,13]$. Fototerapia PUVA lub UVA może być stosowana w monoterapii lub w połączeniu z ww. lekami miejscowymi. W przypadku UVA zaleca się naświetlania 3-5 razy tygodniowo w dawce 50-80 J/ $\mathrm{cm}^{2}$, łącznie 40 ekspozycji. Terapia PUVA wymaga 30 naświetlań 2-4 razy tygodniowo [2, 3, 13].

\section{Twardzina ograniczona linijna (twardzina typu cięcia szablą, postępujący zanik połowiczy twarzy, twardzina linijna kończyn) i głęboka}

Przypadki twardziny ograniczonej linijnej i głębokiej, które przebiegają z zajęciem tkanki podskórnej, powięzi, mięśni, kości i stawów, wymagają agresywnego leczenia w aktywnej fazie choroby [powstawanie nowych ognisk lub powiększanie się już istniejących zmian, lilac ring, zmiany rumieniowe (zapalne), blaszki stwardnieniowe] $[2,3]$. Leczeniem $z$ wyboru są glikokortykosteroidy w postaci dożylnych wlewów metyloprednizolonu w dawce 500-1000 mg/ dobę przez 3 dni. Kuracja powinna być kontynuowana przez co najmniej 3-6 miesięcy. Alternatywę dla leczenia parenteralnego stanowi terapia doustna prednizolonem. Zaleca się podawanie 0,5-2 mg/kg m.c./dobę prednizolonu przez 2-4 tygodnie, a następnie stopniową redukcję dawki [2,3]. Glikokortykosteroidy mogą być stosowane w monoterapii lub w skojarzeniu z MTX. Zalecana dawka MTX u osób dorosłych wynosi 12,5-25 mg tygodniowo. Kuracja powinna być kontynuowana przez co najmniej 12 miesięcy [2,3]. Nietolerancja MTX lub oporność na lek stanowi wskazanie do rozważenia zastosowania MMF (1-2 g/dobę) [2, 3]. Leczenie twardziny linijnej i głębokiej należy rozpoczynać we wczesnej fazie choroby, aby zapobiec powikłaniom, takim jak przykur- 


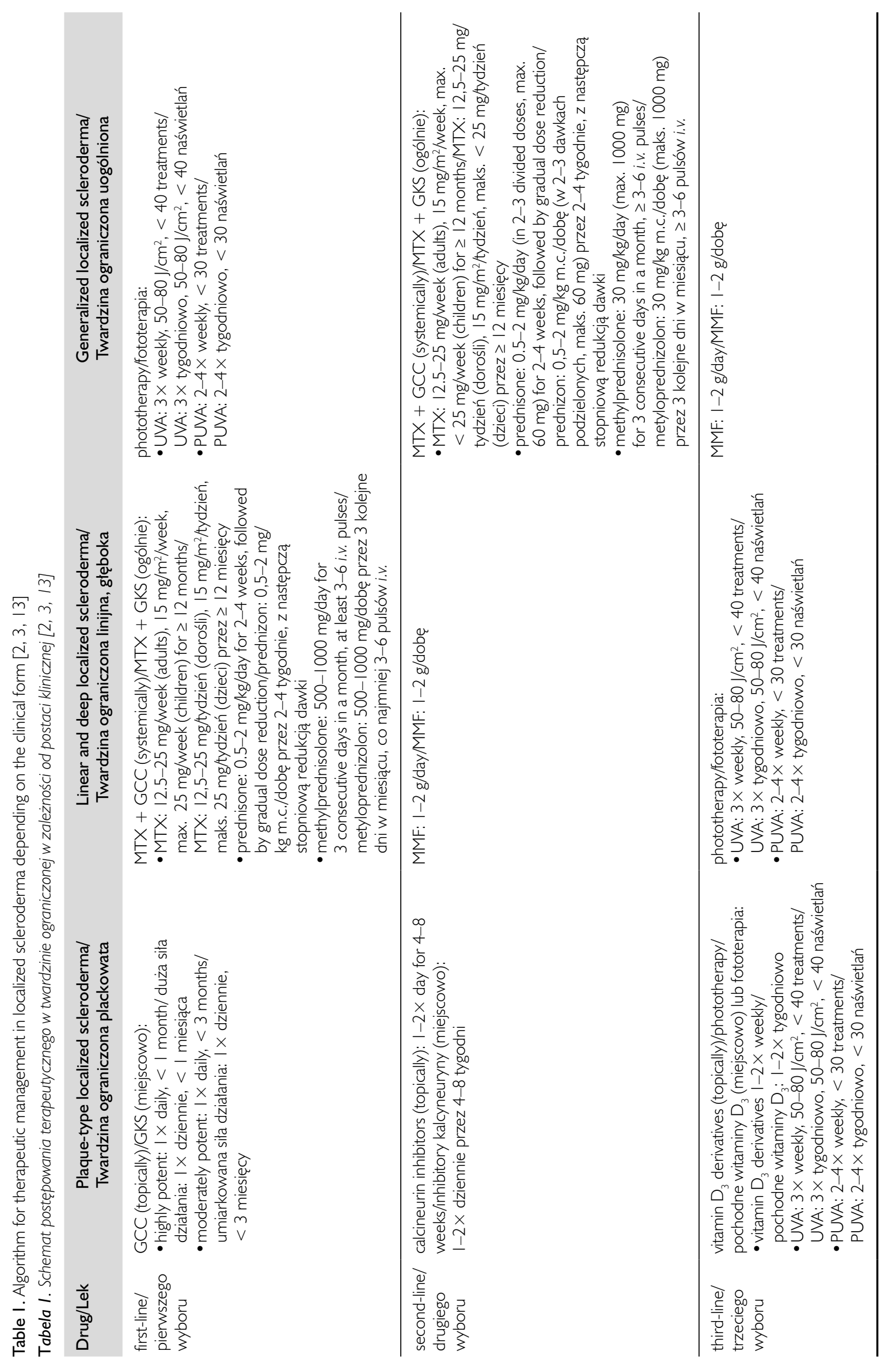




\section{Generalized localized scleroderma}

In the early stages of generalized localized scleroderma, PUVA/UVA phototherapy can be initiated for 4-8 weeks [13]. If the treatment is ineffective and active inflammatory lesions are present, glucocorticoids should be used, either in monotherapy or in combination with methotrexate (at doses given above) $[2,3,13]$. The third-line drug in patients who are intolerant of or refractory to glucocorticoids/MTX is MMF (at doses given above) [2, 3, 13].

\section{THERAPEUTIC MANAGEMENT IN CHILDREN}

Similarly to adults, the choice of therapeutic management in children is determined by the clinical form of the disease, its severity/activity and extent of skin lesions $[2,3,26]$. Paediatric patients with limited skin involvement secondary to localized scleroderma require topical therapy with glucocorticoids, calcineurin inhibitors or phototherapy [2, 3, 26]. Severe forms of the disease, with extensive tissue involvement (particularly the linear type, i.e. the most common clinical form of localized scleroderma in children), require immediate systemic treatment with MTX alone or in combination with glucocorticoids administered via the oral or parenteral route $[2,3]$. The required MTX dose in paediatric patients is $15 \mathrm{mg} / \mathrm{m}^{2} /$ week, maximum $25 \mathrm{mg} /$ week. The therapy should be continued for 12 months as a minimum $[2,3]$. Steroid doses in children must be adjusted to body weight - intravenous pulses of methylprednisolone are administered at a dose of $30 \mathrm{mg} / \mathrm{kg} /$ day (max. 1,000 mg) for 3 days over consecutive 3-6 months; prednisolone orally at a total dose of $0.5-2 \mathrm{mg} / \mathrm{kg} /$ day in 2-3 divided doses (max. $60 \mathrm{mg} /$ day) for 2-4 weeks, followed by gradual dose reduction $[2,3]$.

\section{CONCLUSIONS}

Every clinical form of localized scleroderma requires a slightly different therapeutic approach. The choice of therapeutic modality should be based on prior patient evaluation to determine disease activity and progression, degree of tissue damage, extent of lesions and patients' age. In cases of severe localized scleroderma, aggressive immunosuppressive treatment should be initiated without delay.

\section{CONFLICT OF INTEREST}

The authors declare no conflict of interst. cze dermatogenne, przykurcze stawowe, asymetria kończyn [2,3].

\section{Twardzina ograniczona uogólniona}

We wczesnych etapach rozwoju twardziny ograniczonej uogólnionej można podjąć próbę fototerapii PUVA lub UVA przez 4-8 tygodni [13]. W przypadku jej nieskuteczności i występowania aktywnych zmian zapalnych należy rozpocząć stosowanie glikokortykosteroidów w monoterapii lub w skojarzeniu z MTX (dawki jw.) [2, 3, 13]. Lekiem trzeciego wyboru w przypadku nietolerancji MTX lub oporności na glikokortykosteroidy albo MTX jest MMF (dawki jw.) [2, 3, 13].

\section{POSTĘPOWANIE TERAPEUTYCZNE U DZIECI}

Wybór postępowania terapeutycznego u dzieci, podobnie jak u dorosłych, zależy od postaci klinicznej, nasilenia lub aktywności choroby oraz rozległości wykwitów [2, 3, 26]. Pacjenci pediatryczni z ograniczonym zajęciem skóry w przebiegu twardziny ograniczonej wymagają terapii miejscowej glikokortykosteroidami, inhibitorami kalcyneuryny lub fototerapii $[2,3,26]$. W cięższych odmianach, w których dochodzi do rozległego zajęcia tkanek (szczególnie postać linijna - najczęstsza odmiana kliniczna twardziny ograniczonej u dzieci), należy jak najszybciej zastosować ogólnie MTX w monoterapii lub w skojarzeniu z glikokortykosteroidami stosowanymi doustnie lub parenteralnie [2, 3]. Zalecana dawka MTX u pacjentów pediatrycznych wynosi $15 \mathrm{mg} / \mathrm{m}^{2}$ tygodniowo, maksymalnie $25 \mathrm{mg}$ tygodniowo. Kuracja powinna być kontynuowana przez co najmniej 12 miesięcy $[2,3]$. Steroidoterapia u dzieci wymaga dostosowania dawki do masy ciała - dożylnie pulsy metyloprednizolonu stosuje się w dawce $30 \mathrm{mg} / \mathrm{kg}$ m.c./ dobę (maks. $1000 \mathrm{mg}$ ) przez 3 dni przez kolejne 3-6 miesięcy; prednizolon doustnie $0,5-2 \mathrm{mg} / \mathrm{kg}$ m.c./ dobę w 2-3 dawkach podzielonych (maks. $60 \mathrm{mg} /$ dobę) przez 2-4 tygodnie $\mathrm{z}$ następczą stopniową redukcją dawki $[2,3]$.

\section{PODSUMOWANIE}

Każda z postaci klinicznych twardziny ograniczonej wymaga nieco odmiennego podejścia terapeutycznego. Wybór metody leczenia powinien się opierać na wcześniejszej ocenie u każdego pacjenta aktywności i progresji choroby, stopnia uszkodzenia tkanek, rozległości zmian chorobowych oraz wieku. W przypadku twardziny ograniczonej o ciężkim przebiegu nie należy zwlekać z włączeniem intensywnego leczenia immunosupresyjnego.

\section{KONFLIKT INTERESÓW}

Autorzy deklarują brak konfliktu interesów. 


\section{References}

\section{Piśmiennictwo}

1. Garza R.M., Jacobe H.T.: Morphea. [In:] Treatment of Skin Diseases. Comprehensive Therapeutic Strategies. M.G. Lebwohl, W.R. Heymann, J. Berth-Jones, I. Coulson (eds.), Elsevier, Philadelphia, 2014, 464-466.

2. Knobler R., Moinzadeh P., Hunzelmann N., Kreuter A., Cozzio A., Mouthon L., et al.: European Dermatology Forum S1 guideline on the diagnosis and treatment of sclerosing diseases of the skin. Part 1: localized scleroderma, systemic sclerosis and overlap syndromes. J Eur Acad Dermatol Venereol 2017, 31, 1401-1424.

3. Kreuter A., Krieg T., Worm M., Wenzel J., Moinzadeh P.: German guidelines for the diagnosis and therapy of localized scleroderma. J Dtsch Dermatol Ges 2016, 14, 199-216.

4. Fett N., Wrth V.P.: Update on morphea. Part II. Outcome measures and treatment. J Am Acad Dermatol 2011, 64, 231-242.

5. Kroft E.B., Groeneveld T.J., Seyger M.M., de Jong E.M.: Efficacy of topical tacrolimus $0.1 \%$ in active plaque morphea: randomized, double-blind, emollient-controlled pilot study. Am J Clin Dermatol 2009, 10, 181-187.

6. Stefanaki C., Stefanaki K., Kontochristopoulos G., Antoniou C., Stratigos A., Nicolaidou E., et al.: Topical tacrolimus $0.1 \%$ ointment in the treatment of localized scleroderma. An open label clinical and histological study. J Dermatol 2008, 35, 712-718.

7. Kreuter A., Krieg T., Worm M., Wenzel J., Gambichler T., Kuhn A., et al.: AWMF Guideline no. 013/066. Diagnosis and therapy of circumscribed scleroderma. J Dtsch Dermatol Ges 2009, 7 (Suppl 6): S1-S14.

8. Rodriguex-Castellanos M., Tiacuilo-Parra A., Sanchez-Enriquez S., Velez-Gomez E., Guevara-Gutierrez E.: Pirfenidone gel in patients with localized scleroderma: a phase II study. Arthritis Res Ther 2015, 16, 510.

9. York N.R., Jacob H.T.: UVA1 phototherapy: a review of mechanism and therapeutic application. Int J Dermatol 2010, 49, 623-630.

10. Hassani J., Feldman S.R.: Phototherapy in scleroderma. Dermatol Ther 2016, 6, 519-553.

11. Zwischenberger B.A., Jackobe H.T.: A systematic review of morphea treatments and therapeutic algorithm. J Am Acad Dermatol 2011, 65, 925-941.

12. Vasquez R., Jabbar A., Khan F., Buethe D., Ahn C., Jackobe H.: Recurrence of morphea after successful ultraviolet A1 phototherapy: a cohort study. J Am Acad Dermatol 2014, 70, 481-488.

13. Careta M.F, Romiti R..: Localized scleroderma: clinical spectrum and therapeutic update. An Bras Dermatol 2015, 90, 62-73.

14. Byun J.Y., Lee G.Y., Choi H.Y., Myung K.B., Choi Y.W.: The expressions of TGF-beta and IL-10 in cultured fibroblasts after ALA-IPL photodynamic therapy. Ann Dermatol 2011, 23, 19-22.

15. Marsol B.: Update on the classification and treatment of localized scleroderma. Actas Dermosifiliogr 2013, 104, 654-666.

16. Mertens J.S., van den Reek J.M., Kievit W., van den Kerkhof P.C.M., Thurlings R.M., Radstake T.R.D., et al.: Drug survival and predictors of drug survival for methotrexate treatment in a retrospective cohort of adult patients with localized scleroderma. Acta Derm Venereol 2016, 96, 943-947.

17. Li S.C., Pope E.: Localized scleroderma. [In:] Textbook of Pediatric Rheumatology. R.E. Petty, R. Laxer, C. Lindsley, L. Wedderburn (eds.), Elsevier, Philadelphia, 2015, 406-417.

18. Martini G., Ramanan A.V., Falcini F., Girschick H., Goldsmith D.P., Zulian F.: Successful treatment of severe or methotrexate-resistant juvenile localized scleroderma with mycophenolate mofetil. Rheumatology 2009, 48, 1410-1413.

19. Wen W., Lee S., Siang R., Koh R.: Repurposing pentoxifylline for the treatment of fibrosis: an overview. Adv Ther 2017, 34, 1245-1269.

20. Sosińska P., Baum E., Maćkowiak B., Maj M., Sumińska-Jasińska K., Staniszewski R., et al.: Sulodexide reduces the proinflammatory effect of serum from patients with peripheral artery disease in human arterial endothelial cells. Cell Physiol Biochem 2016, 40, 1005-1012.

21. Borawski J., Dubowski M., Pawlak K., Mysliwiec M.: Effect of sulodexide on plasma transforming growth factor-beta1 in healthy volunteers. Clin Appl Thromb Hemost 2010, 16, 60-65.

22. Bali G., Fruhaul J., Wutte N., Aberer E.: Cyclosporine reduces sclerosis in morphea: a retrospective study in 12 patients and a literature review. Dermatology 2016, 232, 503-510.

23. Thomas R.M., Worswick S., Aleshin M.: Retinoid acid treatment of systemic scleroderma and morphea: a literature review. Dermatol Ther 2017, 30, doi: 10.1111/dth.12455.

24. Deshmukh S.P., Dogra B.B., Sharma Y.K., Deo K.S.: Autologus fat transfer for restoration of facial contour in progressive facial hemiatrophy. Indian J Dermatol Venereol Leprol 2012, 78, 775-778.

25. Shalaby S.M., Bosseila M., Fawzy M.M., Abdel Halim D.M., Sayed S.S., Allam R.S.: Fractional carbon dioxide laser versus low-dose UVA-1 phototherapy for treatment of localized scleroderma: a clinical and immunohistochemical randomized controlled study. Lasers Med Sci 2016, 31, 1707-1715.

26. Timpane S., Brandling-Bennett H., Kristjanson A.K.: Autoimmune collagen vascular diseases: kids are not just little people. Clin Dermatol 2016, 34, 678-689.

Received: 11.08 .2017

Accepted: 9.09.2017

Otrzymano: $11.08 .2017 \mathrm{r}$

Zaakceptowano: 9.09 .2017 r

How to cite this article

Wolska-Gawron K., Michalska-Jakubus M., Krasowska D.: Localized scleroderma - current treatment options. Dermatol Rev/ Przegl Dermatol 2017, 104, 606-618. DOI: https://doi.org/10.5114/dr.2017.71833. 